\title{
PENERAPAN ALGORITMA RABIN KARP PADA APLIKASI KATALOG PAKET UMROH MENGGUNAKAN WEB
}

\author{
Suhartini \\ Program Studi Teknik Informatika STMIK Budi Darma, Medan, Indonesia \\ Email: suhar.tini0212@gmail.com
}

\begin{abstract}
Abstrak
Perjalanan untuk sampai ke Tanah suci terbilang rumit tapi seiring dengan perkembangan zaman, berangkat umroh menjadi mudah sebab sekarang banyak agen perjalanan yang menerima jasa perjalanan umroh. Saat ini banyak agen menerima jasa perjalanan umroh, namun ada juga beberapa agen perjalanan yang ilegal dan tidak tercatat di Kementrian Agama. Agen perjalanan seperti itu banyak merugikan jamaah umroh yang ingin menjalankan ibadah. Dengan harga perjalanan umroh yang murah menjadi daya tarik para jamaah dan tidak memperhatikan legalitas dari agen perjalanan tersebut. Dan pada akhirnya jamaah tidak diberangkatkan dengan berbagai alasan untuk menutupi kejahatan agen perjalanan tersebut. Untuk itu, jamaah membutuhkan aplikasi yang dapat memberikan pencarian informasi paket umroh dengan pertimbangan fasilitas yang sama. Dan dibuatnya aplikasi ini dapat memudahkan calon jamaah umroh dalam memilih fasilitas yang sama dengan harga sesuai kemampuan. Tidak hanya dapat mengetahui harga, calon jamaah juga bisa melihat keterangan fasilitas dan juga keresmian (legalitas) agen perjalanan tersebut. Penelitian ini dilakukan untuk memudahkan calon jamaah umroh dalam memilih fasilitas, harga dan legalitas agen perjalanan tersebut, serta juga menerapkan algoritma Rabin Karpdan merancang aplikasi katalog paket umroh berbasis web.Berdasarkan hasil analisa, sistem ini dapat membantu calon jamaah umroh pengunjung dengan tingkat keberhasilan $79.45 \%$ untuk menentukan hasil pencarian calon jamaah umroh.
\end{abstract}

Kata Kunci: katalog paket umroh, rabin karp, string matching

\section{Abstract}

The journey to get to the Holy Land is somewhat complicated but along with the times, departing Umrah becomes easy because now many travel agents receive Umrah travel services. At present many agents accept Umrah travel services, but there are also some travel agents that are illegal and are not registered with the Ministry of Religion. Such travel agents harm Umrah pilgrims who want to practice their religion. With the price of cheap Umrah trips become an attraction for pilgrims and do not pay attention to the legality of the travel agent. And in the end pilgrims did not depart with various reasons to cover up the crime of the travel agent. For this reason, pilgrims need an application that can provide information searching for Umrah packages with consideration of the same facilities. And making this application can make it easier for prospective pilgrims to choose the same facilities with prices according to ability. Not only can know the price, prospective pilgrims can also see information on facilities and also the officiality (legality) of the travel agent. This research was conducted to make it easier for prospective pilgrims to choose facilities, prices and legality of the travel agent, and also apply the Rabin Karp algorithm and design a web-based Umrah package catalog application. Based on the results of the analysis, this system can help prospective Umrah pilgrims visitors with a success rate of $79.45 \%$ to determine the search results for prospective Umrah pilgrims.

Keywords: umroh package catalog, rabin karp, string matching

\section{PENDAHULUAN}

Umroh memiliki arti yaitu mengunjungi kota Makkah untuk melaksanakan ibadah seperti thawaf dan sa'i juga mengerjakan cara tertentu atau umroh biasanya disebut dengan hajjul asghar atau haji kecil yang artinya berkunjung ke Baitullah, yang mana di dalamnya mengerjakan thawaf, sa' $i$, dan juga bercukur demi mengharap ridho Allah. Ibadah ini adalah rukun iman ke lima, yang mana jika tidak bisa melaksanakan ibadah haji maka boleh mengerjakan ibadah umroh, tujuannya tetap sama yaitu ke Tanah suci hanya umroh berbeda sedikit dengan haji.

Adapun metode yang digunakan dalam mengatasi masalah katalog paket umroh adalah metode String Matching yang merupakan salah satu algoritma yanga biasa digunakan untuk memeriksa suatu kondisi ataupun biasa digunakan untuk mencocokkan sebuah kata atau makna dengan kata yang lain dengan proses yang cukup cepat karena pemeriksaan hanya menghasilkan kondisi cocok atau tidak. Berikut ini adalah beberapa metode String Matching yaitu Boyer Moore, Knuth Morris Pratt, Brute Force, Turbo Boyer Moore dan Rabin Karp. Rabin Karp merupakan pencocokan sebuah string yang memakai hash untuk membandingkan string yang dicari atau (m) dan substring dengan teks atau (n). Jika kedua hash sama maka mengerjakan perbandingan lagi pada karakternya. Dan jika kedua hash tidak sama, lalu substring akan bergeser ke kanan. Pergeseran dikerjakan dengan (n-m) kali.

Algoritma ini bekerja berdasarkan tiga buah parameter yang dapat ditentukan masing-masing, parameter tersebut adalah $\mathrm{K}$-Gram, Basis dan Modulo. Metode ini mempunyai beberapa kombinasi input yang berfungsi mengatur tingkat akurasi, permasalahan yang dihadapi ialah bagaimana menentukan nilai-nilai yang digunakan pada parameter tersebut[1]. Kelebihan algoritma Rabin Karp diantaranya dengan memperhatikan karakter satu persatu dari susunan karakter, tapi cara membandingkannya (perhitungan hash kunci nya) sangat mudah dan kasus pencarian string dengan pola yang panjang[2].

\section{TEORITIS}




\subsection{String Matching}

Algoritma string matching merupakan sebuah algoritma yang dipakai untuk menentukan suatu keakuratan atau nilai dari sebagian dari pola teks yang diberikan[13]. Algoritma pencarian string biasanya disebut dengan pencocokan pada string dimana algoritma yang digunakan sebagai pencarian untuk semua kemunculan pada string pendek ataupun panjang, untuk string pendek disebut pattern, string pendek = pattern [0..n-1] dan string panjang disebut teks, string panjang $=$ teks[0..m-1].Masalah awal pada pencarian pada string yaitu sebagai pencarian pada string yang mana terbagi dari berbagai karakter (yang biasa disebut pattern) dari jumlah besar pada teks.

\subsection{Paket Umroh}

Setiap agen perjalanan umroh mempunyai paket tersendiri, yang mana paket umroh tersebut memilliki keunggulan masing-masing dan juga mempunyai harga yang bervariasi. Berikut ini merupakan contoh paket umroh yang ada pada setiap agen perjalanan yaitu :

1. Paket Umroh Ekonomi (10 hari) (Biaya : Rp 21.000.000,-- )

Fasilitas :

a. Tiket Pesawat Ekonomi Medan - Madinah (Pulang Pergi)

b. Suntik Meningitis

c. Airport Tax dan Handling

d. Akomodasi hotel sesuai paket

e. Transportasi Bus sesuai program

f. Makan 3X sehari menu indonesia

g. Ziarah pada Mekkah dan madinah

h. Muthawif (Guide Local)

i. Manasik, Air Zamzam

j. Visa, Asuransi, Perlengkapan seperti koper bagasi, tas serbaguna, bahan seragam tas jinjing, kain ihrom, mukena dan buku doa

\subsection{Algoritma Rabin Karp}

Algoritma Rabin Karp dibuat pada tahun 1987 dengan Michael O. Rabin dan juga Richard M. Karp. algoritma berguna untuk mencari multi pattern daripada mencari single pattern. Sebab pada algoritma tersebut tidak memperhatikan huruf besar atau huruf kecil dan juga tanda baca yang digunakan. Fungsi hash pada Rabin Karp adalah sebuah fungsi yang digunakan untuk merubah string jadi sebuah integer. Dialgoritma ini string diubah menjadi sebuah integer berdasarkan bilangan ASCII.

Langkah-langkah dalam Rabin Karp antara lain[5]:

1. Menghapus tanda baca juga merubah ke teks.

2. Membagi teks ke dalam Kgram-Kgram yang ditetapkan pada nilai k-gramnya.

3. Pencarian nilai hash menggunakan fungsi hash dari tiap kata yang terbentuk.

4. Pencarian nilai hash yang sama antara dua teks.

Algoritma Rabin Karp merupakan sebuah pencocokan pada string yang digunakan untuk fungsi hash sebagai pembandingan dengan string yang dicari atau (m) dan substring pada teks atau (n). Untuk menentukan nilai hash, rabin karp mengolah dengan rumus berikut :

$H_{\left(c_{1} \ldots c_{k}\right)}=c_{1} * b^{(k-1)}+c_{1} * b^{(k-1)}+\cdots+C_{(k-1)} * b^{k}+c_{k}$

$H_{\left(c_{1} \ldots c_{k+1}\right)}=\left(H_{\left(c_{1} \ldots c_{k}\right)}-c_{1} * b^{(k-1)}\right) * b+c_{(k+1)}$

Dimana :

$\mathrm{H} \quad=$ Nilai Hash (substring)

c $\quad=$ Nilai ASCII per-karakter

$\mathrm{b} \quad=$ Basis

$\mathrm{k}=$ Banyak karakter (panjang karakter)[15].

Berikut beberapa tahapan tahapan yang terdapat dalam algoritma rabin karp antara lain adalah sebagai berikut:

1. Tahap K-Gram

$K$-gram merupakan sebuah rangkaian terms dengan panjang K, terms banyak digunakan sebagai kata. $K$-Gram yaitu suatu metode yang ditampilkan untuk membangkitkan kata dan juga karakter[5]. Metode K-Gram ini dipakai sebagai pengambil beberapa potongan karakter huruf dengan banyak jumlah k pada teks sumber sampai akhir dari dokumen.

2. Tahap Hashing 
Hashing yaitu sebuah cara untuk menyelesaikan pada suatu string sebagai suatu nilai yang unik pada panjang tertentu dan berfungsi untuk menandai string tersebut[5]. Fungsi hashing merupakan metode yang sederhana sebagai menjauhi perbandingan pada jumlah quardratik dalam kasus dan situasi.

3. Tahap Fingerprint

Kumpulan nilai hash disebut fingerprint. Jika nilai hash sama maka tidak dimasukkan ke fingerprint. Dengan algoritma Rabin Karp hasil dari kedua fingerprint maka kedua dokumen yang memiliki kesamaan bisa diambil, hingga solusi dapat ditetukan[6].

4. Tahap Similarity

Dices's Similarity Coficient merupakan suatu analisis yang digunakan untuk mencari tahu dokumen paling relavan untuk himpunan kata kunci yang mempunyai nilai yang sama untuk digunakan pada nilai similarity[6]. Yang dihitung menggunakan rumus :

$s=\frac{n_{f}}{n_{u j i}} \times 100$

Keterangan:

Jumlah nilai hash data fasilitas $\left(n_{(u j i)}\right)$

Jumlah nilai hash data pencarian yang sama $\left(n_{f}\right)$

\section{ANALISA DAN PERANCANGAN}

Salah satu fasilitas dengankelas ekonomi yaitu terdiri dari tiket pesawat pulang pergi, visa umroh, transportasi bus AC, makan 3 kali, akomodasi hotel sesuai paket, guide atau muthowif berbahasa indonesia juga Arab, air zam-zam 1 galon perorang, bimbingan manasik sebelum keberangkatan, asuransi perjalanan dan fasilitas dengan kelas lainnya dari setiap agen perjalanan umroh dan lainnya. Selama ini calon jamaah mencari sebuah agen perjalanan yang sesuai dengan keinginan mereka, maka dari itu penulis merancang sebuah aplikasi yang bisa membantu calon jamaah untuk pemilihan suatu agen perjalanan yang sesuai dengan kriteria dan memudahkan calon jamaah.

Dengan merancang aplikasi ini penulis menggunakan Rabin Karp dalam penyelesaiannya. Algoritma ini digunakan sebagai pencarian informasi untuk paket umroh, dimanasecara garis besar penulis melakukan pencarian kelas, harga, akomodasi hotel dan lainnya menggunakan algoritma Rabin Karp. Selain itu,aplikasi yang dirancang ini merupakan aplikasi yang berbasis web yang digunakan untuk membangun sebuah aplikasi pencarian tersebut.Berikut ini merupakan tahap yang dilakukan dalam melakukan penelitian ini adalah:

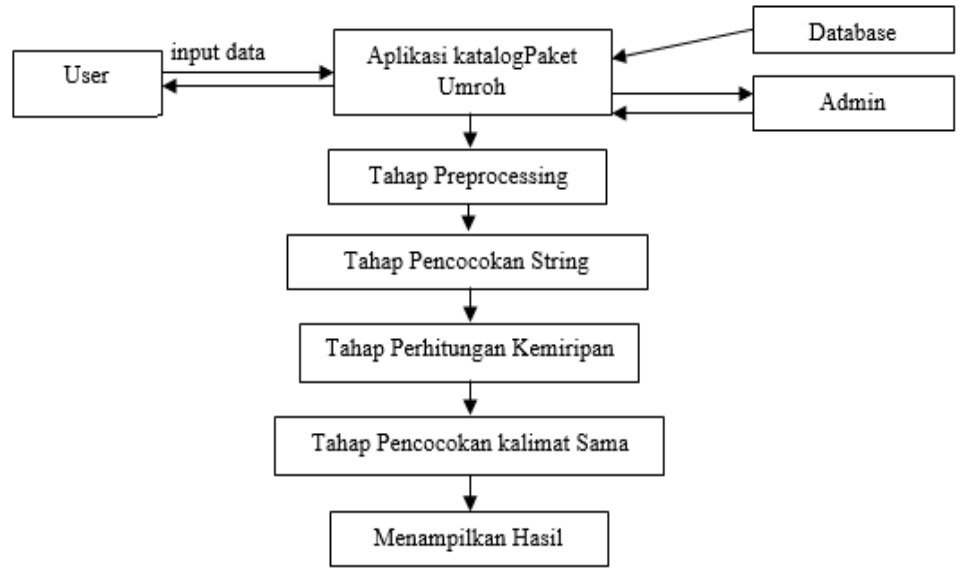

Gambar 1. Tahapan tahapan yang dilakukan

Berikut ini merupakan contoh pencarian data fasilitas yang ingin dicari oleh calon jamaah umroh adalah sebagai berikut:

Tabel 1. Pencarian Data Fasilitas Calon Jamaah

Pencarian Data Fasilitas

Pesawat Saudi Airline, Akomodasi Hotel Madinah dan

Makkah Bintang empat, Visa Umroh, Transportasi Bus AC,

Asuransi, Buku Panduan Umroh, Perlengkapan Umroh,

Makanan Menu Indonesia, Air Zam-Zam, Kain Ihram dan

Rompi, Ziarah dan City tour

Tabel 2. Contoh Data Fasilitas 1

Data Fasilitas 1 
Pesawat Saudi Airline, Akomodasi Hotel Madinah dan

Makkah Bintang tiga, Visa Umroh, Transportasi Bus AC, Manasik, Perlengkapan Umroh, Makanan menu Indonesia, Air Zamzam, Buku Panduan Umroh, Kain Ihram dan Rompi,Ziarah dan City Tour.

Tabel 3. Contoh Data Fasilitas 2

Data Fasilitas 2

Pesawat Saudi Airline, Akomodasi Hotel Madinah dan Makkah Bintang empat, Visa Umroh, Transportasi Bus AC, Manasik, Asuransi, Perlengkapan Umroh, Makanan Menu Indonesia, Muthawif, Air Zamzam, Kain Ihram dan Rompi, Ziarah, Suntik Meningitis.

Tabel 4. Contoh Data Fasilitas 3

Data Fasilitas 3

Pesawat Saudi Airline, Akomodasi Hotel Madinah dan

Makkah Bintang lima, Visa Umroh, Transportasi Bus AC,

Manasik, Asuransi, Perlengkapan Umroh, Makanan Menu

Indonesia, Muthawif, Air Zamzam, Kain Ihram dan Rompi,

Ziarah di Makkah, Madinah dan Jeddah, Suntik Meningitis.

Dan tabel fasilitas 1, fasilitas 2, fasilitas 3 ini merupakan contoh data fasilitas yang diambil dari beberapa agen perjalanan umroh. Dimana data ini akan dicocokan dengan data fasilitas dari calon jamaah umroh.

\subsection{Penerapan Algoritma Rabin Karp}

Dalam menerapkan algoritma Rabin Karp ini dilakukan setelah melalui tahap preprocessing, pada tahap preprocessing teks ini diambil dan dihilangkan simbol, karakter spesial, spasi dan mengubah huruf besar menjadi huruf kecil.

Tabel 5. Tahap Preprocessing Pencarian Data Fasilitas Calon Jamaah

Pencarian Data Fasilitas Hasil Preprocessing

Pesawat Saudi Airline, Akomodasi Hotel Madinah dan Pesawatsaudiairlineakomodasihotelmadinahdanmak Makkah Bintang empat, Visa Umroh, Transportasi Bus kahbintangempatvisaumrohtransportasibusacasuran AC, Asuransi, Buku Panduan Umroh, Perlengkapan sibukupanduanumrohperlengkapanumrohmakanan Umroh, Makanan Menu Indonesia, Air Zam-Zam, Kain menuindonesiaairzamzamkainihramdanrompiziarah Ihram dan Rompi, Ziarah dan city tour dancitytour

Tabel diatas merupakan tahap preprocessing pada pencarian data fasilitas. Dan juga sama pengerjaannya dengan data fasilitas 1 , fasilitas 2 dan fasilitas 3 .

1. Tahap $K$-Gram

Pada hasil preprocessing dikerjakan memakai algoritma Rabin Karp dan menerapkan $K$-Gram. Kemudian metode ini mendapatkan menyusun substring sebanyak jumlah k-gram, yang mana $\mathrm{k}$ merupakan parameter yang ditentukan user. Tahap ini merupakan pemotongan sebuah karakter sesuai nilai k yang ditentukan 3,4 dan 5. Dimana nilainya dapat ditentukan sesuai kebutuhan, tapi dalam penelitian ini menggunakan nilai $k$-gram yang lebih kecil seperti 3, 4 dan 5, namun pada tabel-tabel berikut menggunakan contoh $k$-grampencarian data fasilitas, data fasilitas 1 , data fasilitas 2 dan data fasilitas 3 dengan nilai $\mathrm{k}=5$.

Tabel 6. Tahap K-Gram padaPencarian Data Fasilitas dengan Nilai k=5

\begin{tabular}{ll}
\hline \multicolumn{1}{c}{ Pencarian Data Fasilitas } & \multicolumn{1}{c}{ Hasil Preprocessing } \\
\hline $\begin{array}{l}\text { pesawatsaudiairlineakomodasihotelmadinah } \\
\text { danmakkahbintangempatvisaumrohtransport }\end{array}$ & upesaw $\}\{$ esawa $\}\{$ sawat $\}\{$ awats $\}\{$ watsa $\}\{$ atsau $\}\{$ tsaud $\}\{$ sa \\
asibusacasuransibukupanduanumrohperleng & $\{$ ineak $\}\{$ neako $\}\{$ eakom $\}\{$ diakomo $\}\{$ komod $\}\{$ omoda $\}\{$ modas \\
kapanumrohmakananmenuindonesiaairzamz & \}$\{$ odasi $\}\{$ dasih $\}\{$ asiho $\}\{$ sihot $\}\{$ ihote $\}\{$ hotel $\}\{$ otelm $\}\{$ telm \\
amkainihramdanrompiziarahdancitytour & a $\{$ elmad $\{\{$ lmadi $\}\{$ madin $\}\{$ adina $\}\{$ dinah $\} \ldots . .$. ytour $\}$
\end{tabular}

Tabel diatas merupakan tahap K-Gram pada pencarian data fasilitas. Dan juga sama pengerjaannya dengan data fasilitas 1 , fasilitas 2 dan fasilitas 3. 


\section{Tahap Hashing}

Berikut ini merupakan pencarian data fasilitas calon jamaah. Dan juga nilai desimal dari nilai ASCII yang dilihat pada tabel-tabel dibawah ini, yang memiliki basis yang ditentukan adalah 10 .

Tabel 7. Nilai ASCII Pencarian Data Fasilitas

\begin{tabular}{|c|c|c|c|c|c|c|c|c|c|c|}
\hline \multirow[b]{2}{*}{ No } & \multicolumn{5}{|c|}{ K-Gram k=5 } & \multicolumn{5}{|c|}{ Nilai ASCII } \\
\hline & $C 1$ & $C 2$ & $C 3$ & $C 4$ & $C 5$ & $C 1$ & $C 2$ & $C 3$ & $C 4$ & $C 5$ \\
\hline 1 & $\mathrm{p}$ & $\mathrm{e}$ & $\mathrm{s}$ & $\mathrm{a}$ & w & 112 & 101 & 115 & 97 & 119 \\
\hline 2 & $\mathrm{e}$ & $\mathrm{s}$ & $\mathrm{a}$ & $\mathrm{w}$ & $\mathrm{a}$ & 101 & 115 & 97 & 119 & 97 \\
\hline 3 & $\mathrm{~s}$ & a & w & $\mathrm{a}$ & $\mathrm{t}$ & 115 & 97 & 119 & 97 & 116 \\
\hline 4 & $\mathrm{a}$ & $\mathrm{w}$ & $\mathrm{a}$ & $\mathrm{t}$ & s & 97 & 119 & 97 & 116 & 115 \\
\hline 5 & $\mathrm{w}$ & $\mathrm{a}$ & $\mathrm{t}$ & $\mathrm{s}$ & a & 119 & 97 & 116 & 115 & 97 \\
\hline 6 & $\mathrm{a}$ & $\mathrm{t}$ & $\mathrm{s}$ & $\mathrm{a}$ & $\mathrm{u}$ & 97 & 116 & 115 & 97 & 117 \\
\hline 7 & $\mathrm{t}$ & $\mathrm{s}$ & $\mathrm{a}$ & $\mathrm{u}$ & d & 116 & 115 & 97 & 117 & 100 \\
\hline 8 & $\mathrm{~s}$ & $\mathrm{a}$ & $\mathrm{u}$ & d & $\mathrm{i}$ & 115 & 97 & 117 & 100 & 105 \\
\hline 9 & $\mathrm{a}$ & $\mathrm{u}$ & d & $\mathrm{i}$ & a & 97 & 117 & 100 & 105 & 97 \\
\hline 10 & $\mathrm{u}$ & d & $\mathrm{i}$ & $\mathrm{a}$ & $\mathrm{i}$ & 117 & 100 & 105 & 97 & 105 \\
\hline 11 & d & $\mathrm{i}$ & $\mathrm{a}$ & $\mathrm{i}$ & $\mathrm{r}$ & 100 & 105 & 97 & 105 & 114 \\
\hline 12 & $\mathrm{i}$ & $\mathrm{a}$ & $\mathrm{i}$ & $\mathrm{r}$ & 1 & 105 & 97 & 105 & 114 & 108 \\
\hline 13 & $\mathrm{a}$ & $\mathrm{i}$ & $\mathrm{r}$ & 1 & i & 97 & 105 & 114 & 108 & 105 \\
\hline 14 & $\mathrm{i}$ & $\mathrm{r}$ & 1 & $\mathrm{i}$ & $\mathrm{n}$ & 105 & 114 & 108 & 105 & 110 \\
\hline 15 & $\mathrm{r}$ & 1 & i & $\mathrm{n}$ & $\mathrm{e}$ & 114 & 108 & 105 & 110 & 101 \\
\hline 16 & 1 & $\mathrm{i}$ & $\mathrm{n}$ & $\mathrm{e}$ & $\mathrm{a}$ & 108 & 105 & 110 & 101 & 97 \\
\hline 17 & i & $\mathrm{n}$ & $\mathrm{e}$ & a & $\mathrm{k}$ & 105 & 110 & 101 & 97 & 107 \\
\hline 18 & $\mathrm{n}$ & $\mathrm{e}$ & $\mathrm{a}$ & $\mathrm{k}$ & o & 110 & 101 & 97 & 107 & 111 \\
\hline 19 & $\mathrm{e}$ & a & $\mathrm{k}$ & o & $\mathrm{m}$ & 101 & 97 & 107 & 111 & 109 \\
\hline 20 & $\mathrm{a}$ & $\mathrm{k}$ & o & $\mathrm{m}$ & o & 97 & 107 & 111 & 109 & 111 \\
\hline 187 & $\cdots$ & $\cdots$ & $\cdots$ & $\cdots$ & $\cdots$ & 121 & $\ldots$ & $\ldots$ & $\ldots$ & 114 \\
\hline
\end{tabular}

Berikut ini merupakan perhitungan Hashing, dimana menggunakan pencarian data fasilitas adalah:

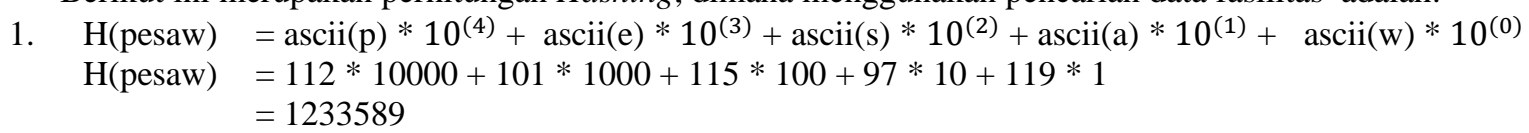

2. $\mathrm{H}($ esawa $)=\left(\mathrm{H}_{(\text {pesaw })}-\operatorname{ascii}(\mathrm{p}) * 10^{(4)}\right) * 10+\operatorname{ascii}(\mathrm{a})$

$\mathrm{H}($ esawa $)=(1233589-112 * 10000) * 10+97=1135987$

3. $\mathrm{H}($ sawat $)=\operatorname{ascii}(\mathrm{s}) * 10^{(4)}+\operatorname{ascii}(\mathrm{a}) * 10^{(3)}+\operatorname{ascii}(\mathrm{w}) * 10^{(2)}+\operatorname{ascii}(\mathrm{a}) * 10^{(1)}+\operatorname{ascii}(\mathrm{t}) * 10^{(0)}$

$\mathrm{H}$ (sawat) $=115 * 10000+97 * 1000+119 * 100+97 * 10+116 * 1$

$$
=1259986
$$

4. $\mathrm{H}($ awats $)=\left(\mathrm{H}_{(\text {sawat })}-\operatorname{ascii}(\mathrm{s}) * 10^{(4)}\right) * 10+\operatorname{ascii}(\mathrm{s})$

$\mathrm{H}($ awats $) \quad=(1259986-115 * 10000) * 10+115=1099975$

5. $\mathrm{H}($ watsa $)=\operatorname{ascii}(\mathrm{w}) * 10^{(4)}+\operatorname{ascii}(\mathrm{a}) * 10^{(3)}+\operatorname{ascii}(\mathrm{t}) * 10^{(2)}+\operatorname{ascii}(\mathrm{s}) * 10^{(1)}+\operatorname{ascii}(\mathrm{a}) * 10^{(0)}$

$\mathrm{H}$ (watsa) $=119 * 10000+97 * 1000+116 * 100+115 * 10+97 * 1$

$=1299847$

6. $\mathrm{H}($ atsau $)=\left(\mathrm{H}_{(\text {watsa })}-\operatorname{ascii}(\mathrm{w}) * 10^{(4)}\right) * 10+\operatorname{ascii}(\mathrm{u})$

$\mathrm{H}($ atsau $) \quad=(1299847-119 * 10000) * 10+117=1098587$

7. $\mathrm{H}(\mathrm{tsaud})=\operatorname{ascii}(\mathrm{t}) * 10^{(4)}+\operatorname{ascii}(\mathrm{s}) * 10^{(3)}+\operatorname{ascii}(\mathrm{a}) * 10^{(2)}+\operatorname{ascii}(\mathrm{u}) * 10^{(1)}+\operatorname{ascii}(\mathrm{d}) * 10^{(0)}$

$\mathrm{H}(\mathrm{tsaud}) \quad=112 * 10000+101 * 1000+115 * 100+97 * 10+119 * 1$

$$
=1233589
$$

8. $\mathrm{H}\left(\right.$ saudi) $=\left(\mathrm{H}_{\text {(tsaud }}-\operatorname{ascii}(\mathrm{t}) * 10^{(4)}\right) * 10+\operatorname{ascii}(\mathrm{i})$

$\mathrm{H}$ (saudi) $\quad=(1233589-112 * 10000) * 10+97=1135987$

9. $\mathrm{H}($ audia $)=\operatorname{ascii}(\mathrm{a}) * 10^{(4)}+\operatorname{ascii}(\mathrm{u}) * 10^{(3)}+\operatorname{ascii}(\mathrm{d}) * 10^{(2)}+\operatorname{ascii}(\mathrm{i}) * 10^{(1)}+\operatorname{ascii}(\mathrm{a}) * 10^{(0)}$

$\mathrm{H}($ audia $) \quad=97 * 10000+117 * 1000+100 * 100+105 * 10+97 * 1$

$=1098147$

10. $\mathrm{H}($ udiai $)=\left(\mathrm{H}_{(\text {audia })}-\operatorname{ascii}(\mathrm{a}) * 10^{(4)}\right) * 10+\operatorname{ascii}(\mathrm{i})$ 
$\mathrm{H}($ udiai) $\quad=(1098147-97 * 10000) * 10+105=1281575$

Dan pada pencarian data fasilitas maka perhitungan nilai hash dilanjutkan sampai nomor 187 pada tabel pencarian data fasilitas. Dan juga data fasilitas 1, fasilitas 2 dan fasilitas 3.

3. Tahap Fingerprint

Setelah tahap hashing selesai, maka nilai hashing yang terkumpul disebut nilai fingerprint. Dan dengan hasil fingerprint dari data fasilitas yang akan diambil maka solusi dapat ditentukan.

Tabel 8. Nilai Hashing pada Pencarian Data Fasilitas Calon Jamaah

\begin{tabular}{|c|c|c|c|c|c|c|c|c|}
\hline $\mathrm{No}$ & Data & Hash & $\mathrm{No}$ & Data & Hash & $\mathrm{No}$ & Data & Hash \\
\hline 1 & pesaw & 1233589 & 64 & saumr & 1259904 & 127 & ohmak & 1225977 \\
\hline 2 & esawa & 1135987 & 65 & aumro & 1099151 & 128 & hmaka & 1159867 \\
\hline 3 & sawat & 1259986 & 66 & umroh & 1291614 & 129 & makan & 1198780 \\
\hline 4 & awats & 1099975 & 67 & mroht & 1216256 & 130 & akana & 1087897 \\
\hline 5 & watsa & 1299847 & 68 & rohtr & 1262674 & 131 & kanan & 1179080 \\
\hline 6 & atsau & 1098587 & 69 & ohtra & 1226837 & 132 & ananm & 1090909 \\
\hline 7 & tasud & 1233589 & 70 & htran & 1168480 & 133 & nanme & 1209191 \\
\hline 8 & saudi & 1135987 & 71 & trans & 1284915 & 134 & anmen & 1092020 \\
\hline 9 & audia & 1098147 & 72 & ransp & 1249262 & 135 & nmenu & 1220317 \\
\hline 10 & udiai & 1281575 & 73 & anspo & 1092731 & 136 & menui & 1203275 \\
\hline 11 & diair & 1115864 & 74 & nspor & 1227424 & 137 & enuin & 1132860 \\
\hline 12 & iairl & 1158748 & 75 & sport & 1274356 & 138 & nuind & 1228700 \\
\hline 13 & airli & 1087585 & 76 & porta & 1243657 & 139 & uindo & 1287111 \\
\hline 14 & irlin & 1175960 & 77 & ortas & 1236685 & 140 & indon & 1171220 \\
\hline 15 & rline & 1259701 & 78 & rtasi & 1266955 & 141 & ndone & 1212301 \\
\hline 16 & linea & 1197107 & 79 & tasib & 1269648 & 142 & dones & 1123125 \\
\hline 17 & ineak & 1171177 & 80 & asibu & 1096597 & 143 & onesi & 1231355 \\
\hline 18 & neako & 1211881 & 81 & sibus & 1266085 & 144 & nesia & 1213647 \\
\hline 19 & eakom & 1118919 & 82 & ibusa & 1160947 & 145 & esiaa & 1136567 \\
\hline 20 & akomo & 1089301 & 83 & busac & 1109569 & 146 & siaai & 1265775 \\
\hline 21 & komod & 1192111 & 84 & usaca & 1295789 & 147 & iaair & 1157864 \\
\hline 22 & omoda & 1221207 & 85 & sacas & 1258105 & 148 & aairz & 1078762 \\
\hline 23 & modas & 1212085 & 86 & acasu & 1081165 & 149 & airza & 1087717 \\
\hline 24 & odasi & 1220955 & 87 & casur & 1111784 & 150 & irzam & 1177279 \\
\hline 25 & dasih & 1109654 & 88 & asura & 1217954 & 151 & rzamz & 1272912 \\
\hline 26 & asiho & 1096651 & 89 & suran & 1108197 & 152 & zamza & 1329217 \\
\hline 27 & sihot & 1266626 & 90 & urans & 1382080 & 153 & amzam & 1092279 \\
\hline 28 & ihote & 1166361 & 91 & ransi & 1249255 & 154 & mzamk & 1222897 \\
\hline 29 & hotel & 1163718 & 92 & ansib & 1092648 & 155 & zamka & 1329067 \\
\hline 30 & otelm & 1237289 & 93 & nsibu & 1226597 & 156 & amkai & 1090775 \\
\hline 31 & telma & 1272987 & 94 & sibuk & 1266077 & 157 & mkain & 1207860 \\
\hline 32 & elmad & 1129970 & 95 & ibuku & 1160887 & 158 & kaini & 1178705 \\
\hline 33 & Imadi & 1199805 & 96 & bukup & 1108982 & 159 & ainih & 1087154 \\
\hline 34 & madin & 1198160 & 97 & ukupa & 1289917 & 160 & inihr & 1171654 \\
\hline 35 & adina & 1081697 & 98 & kupan & 1199280 & 161 & nihra & 1216637 \\
\hline 36 & dinah & 1117074 & 99 & upand & 1292900 & 162 & ihram & 1166479 \\
\hline 37 & inahd & 1170840 & 100 & pandu & 1229117 & 163 & hramd & 1164890 \\
\hline 38 & nahda & 1208497 & 101 & andua & 1091267 & 164 & ramda & 1248997 \\
\hline 39 & ahdan & 1085080 & 102 & nduan & 1212780 & 165 & amdan & 1090080 \\
\hline 40 & hdanm & 1150909 & 103 & duanu & 1127917 & 166 & mdanr & 1200914 \\
\hline 41 & danma & 1109187 & 104 & uanum & 1279279 & 167 & danro & 1109251 \\
\hline 42 & anmak & 1091977 & 105 & anumr & 1092904 & 168 & anrom & 1092619 \\
\hline 43 & nmakk & 1219877 & 106 & numro & 1229151 & 169 & nromp & 1226302 \\
\hline 44 & makka & 1198867 & 107 & umroh & 1291614 & 170 & rompi & 1263125 \\
\hline 45 & akkah & 1088774 & 108 & mrohp & 1216262 & 171 & ompiz & 1231372 \\
\hline 46 & kkahb & 1187838 & 109 & rohpe & 1262621 & 172 & mpizi & 1213825 \\
\hline 47 & kahbi & 1178485 & 110 & ohper & 1226324 & 173 & pizia & 1238347 \\
\hline 48 & ahbin & 1084960 & 111 & hperl & 1163348 & 174 & iziar & 1183584 \\
\hline
\end{tabular}




$\begin{array}{lllllllll}49 & \text { hbint } & 1149716 & 112 & \text { perle } & 1233581 & 175 & \text { ziara } & 1335937 \\ 50 & \text { binta } & 1097257 & 113 & \text { erlen } & 1135920 & 176 & \text { iarah } & 1159474 \\ 51 & \text { intan } & 1172680 & 114 & \text { rleng } & 1259303 & 177 & \text { arahd } & 1094840 \\ 52 & \text { ntang } & 1226903 & 115 & \text { lengk } & 1193137 & 178 & \text { rahda } & 1248497 \\ 53 & \text { tange } & 1269131 & 116 & \text { engka } & 1131467 & 179 & \text { ahdan } & 1085080 \\ 54 & \text { angem } & 1091419 & 117 & \text { ngkap } & 1214782 & 180 & \text { hdanc } & 1150899 \\ 55 & \text { ngemp } & 1214302 & 118 & \text { gkapa } & 1147917 & 181 & \text { danci } & 1109095 \\ 56 & \text { gempa } & 1143117 & 119 & \text { kapan } & 1179280 & 182 & \text { ancit } & 1091066 \\ 57 & \text { empat } & 1131286 & 120 & \text { apanu } & 1092917 & 183 & \text { ncity } & 1210781 \\ 58 & \text { mpatv } & 1212978 & 121 & \text { panum } & 1229279 & 184 & \text { cityt } & 1107926 \\ 59 & \text { patvi } & 1229885 & 122 & \text { anumr } & 1092904 & 185 & \text { ityto } & 1179371 \\ 60 & \text { atvis } & 1098965 & 123 & \text { numro } & 1229151 & 186 & \text { tytou } & 1293827 \\ 61 & \text { tvisa } & 1289747 & 124 & \text { umroh } & 1291614 & 187 & \text { ytour } & 1338384 \\ 62 & \text { visau } & 1297587 & 125 & \text { mrohm } & 1216249 & & & \\ 63 & \text { isaum } & 1175979 & 126 & \text { rohma } & 1262587 & & & \end{array}$

Keterangan :

Warna merah : hash yang berbeda pencarian data calon jamaah

Warna hitam : hash yang sama pencarian data calon jamaah

Dan juga Nilai Hashing pada data fasilitas 1, fasilitas 2 dan fasilitas 3.

4. Tahap Similarity

Lalu setelah mendapatkan nilai hash dari data fasilitas, selanjutnya menghitung nilai similarity dari nilai fingerprint.

Dimana nilai pencarian data fasilitas calon jamaah mencari kemiripan dengan fasilitas 1, fasilitas 2 dan fasilitas 3 .

Dibawah ini merupakan nilai similarity dihitung berdasarkan nilai fingerprint-nya adalah sebagai berikut :

\begin{tabular}{ccc}
\multicolumn{3}{c}{ Tabel 9. Nilai Similarity } \\
\hline Nilai Fasilitas & $\left(n_{(u j i)}\right)$ & $\left(n_{f}\right)$ \\
\hline Data Fasilitas 1 & 185 & 147 \\
Data Fasilitas 2 & 191 & 123 \\
Data Fasilitas 3 & 214 & 141 \\
\hline
\end{tabular}

Tabel 10. Hasil Perhitungan Nilai Similarity

\begin{tabular}{lc}
\hline \multicolumn{1}{c}{$\mathrm{k}=5$} & Basis $=10$ \\
\hline Data fasilitas 1 & $79.45 \%$ \\
Data fasilitas 2 & $64.39 \%$ \\
Data fasilitas 3 & $65.88 \%$ \\
Nilai Similarity kemiripan pada pencarian data fasilitas calon jamaah & $79.45 \%$ \\
\hline
\end{tabular}

Dari hasil nilai similarity diatas, dapat disimpulkan bahwa pencarian data fasilitas yang kemiripannya mendekati data pencarian adalah Data Fasilitas 1 dengan nilai similarity (79.45\%).

\section{IMPLEMENTASI}

\subsection{Interface Program}

Katalog paket umroh yang dirancang merupakan aplikasi berbasis web, dimana katalog paket umroh tersebut dapat dijalankan melalui sistem komputer berbasis web. Aplikasi katalog paket umroh menggunakan bahasa pemograman PHP,HTML dan CSS, dimana untuk mengetik source code pemogramannya penulis menggunakan Sublime Text 3. 


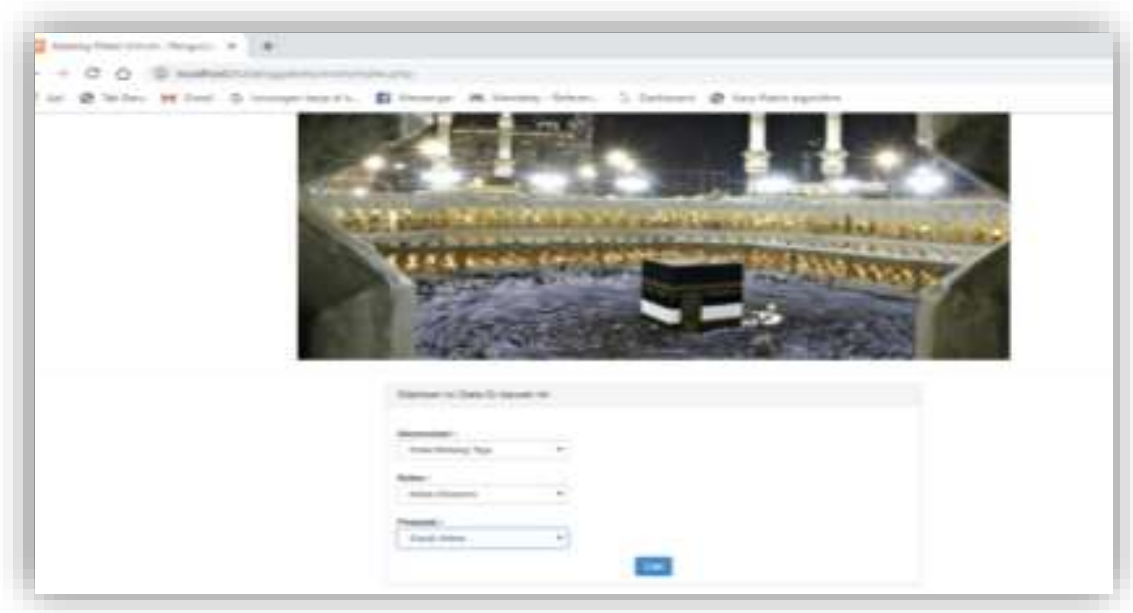

Gambar 2. Tampilan Pencarian Paket Umroh

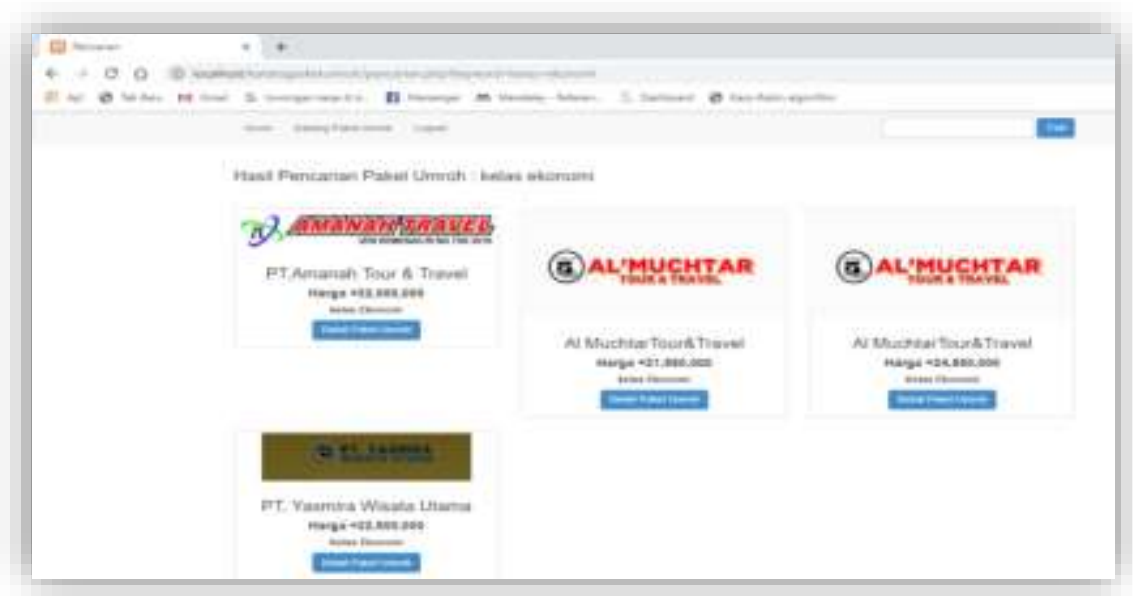

Gambar 3. Tampilan Hasil Pencarian Paket Umroh

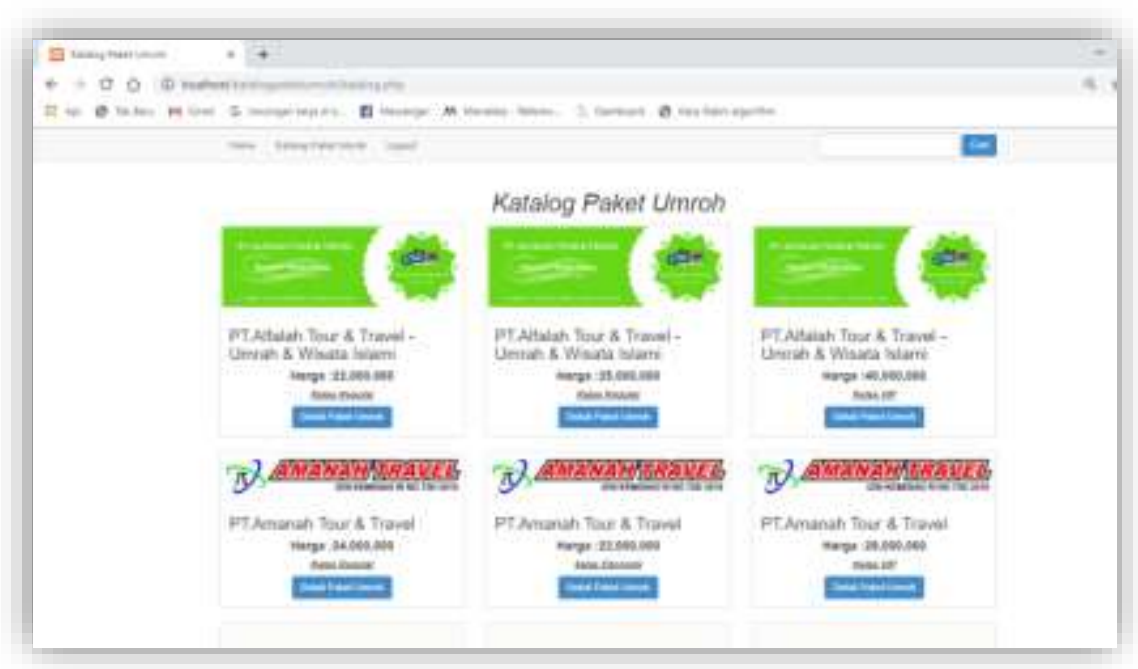

\subsection{Hasil Pengujian Program}

Gambar 4. Tampilan Katalog Paket Umroh

Berikut ini adalah hasil adalah hasil pencarian kata pada aplikasi katalog paket umroh. Hasil pencarian dapat dilihat pada tabel 11. berikut : 
Tabel 11. Tabel Hasil Pengujian

\begin{tabular}{|c|c|c|c|}
\hline No & Kata yang dicari & Status & Hasil Pencarian \\
\hline 1 & $\begin{array}{l}\text { - Akomodasi : Hotel } \\
\text { Bintang Tiga } \\
\text { - Kelas : Kelas Ekonomi } \\
\text { - Pesawat : Saudi Airline }\end{array}$ & Ditemukan & 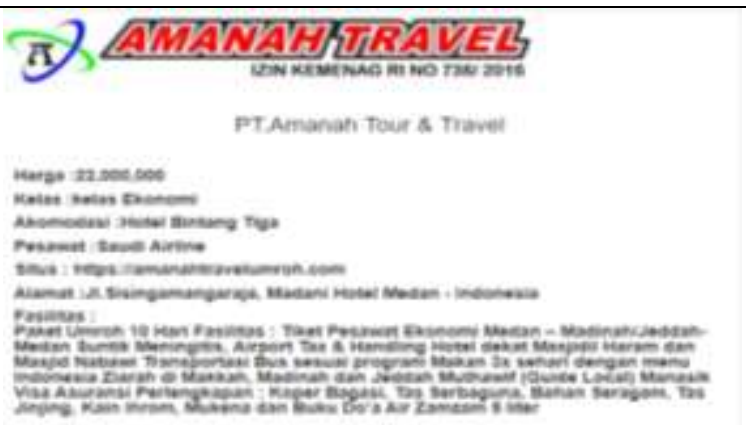 \\
\hline 2 & $\begin{array}{l}\text { - Akomodasi : Hotel } \\
\text { Bintang Empat } \\
\text { - Kelas : Kelas Regular } \\
\text { - Pesawat : Saudi Airline }\end{array}$ & Ditemukan & 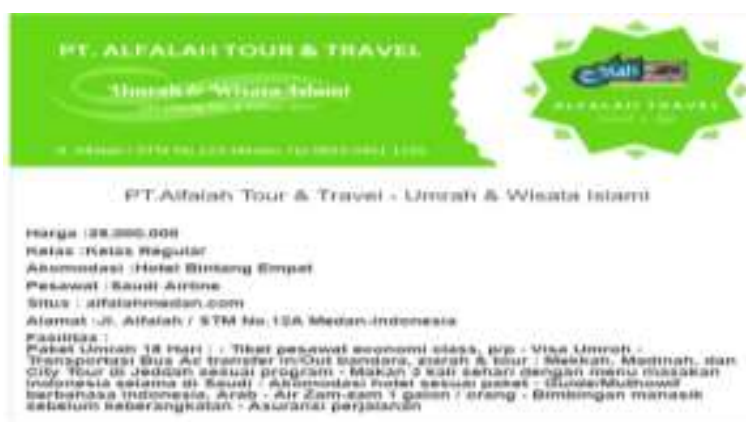 \\
\hline 3 & $\begin{array}{l}\text { - Akomodasi : Hotel } \\
\text { Bintang Lima } \\
\text { - Kelas : Kelas VIP } \\
\text { - Pesawat : Saudi Airline }\end{array}$ & Ditemukan & 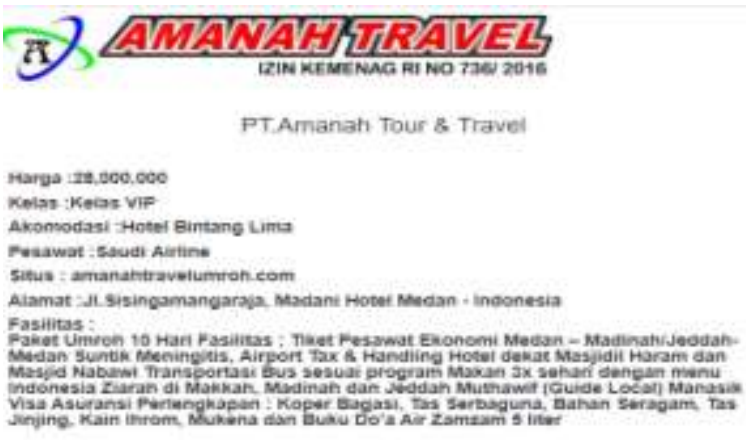 \\
\hline
\end{tabular}

\section{KESIMPULAN}

Dari pembahasan pada bab-bab sebelumnya, maka penulis mengambil kesimpulan adalah:

1. Proses pencarian katalog paket umroh dilakukan dengan cara mencari paket umroh dari setiap agen perjalanan yang sesuai dengan keinginan calon jamaah umroh.

2. Metode Rabin Karp dapat ditetapkan untuk mencari informasi pada katalog paket umroh.

3. Aplikasi katalog paket umroh telah selesai dirancang dengan menggunakan bahasa PHP dan HTML dan dapat dipakai untuk mencari paket umroh sesuai yang diinginkan.

\section{REFERENCES}

[1] A. K-gram, B. Dan, and M. R. Sebagai, “Analisis k-gram, basis dan modulo rabin-karp sebagai penentu akurasi persentase kemiripan dokumen,” pp. 198-206, 2017.

[2] H. Mahfud and T. Pramiyati, "ANALISIS PENGUKURAN SELF PLAGIARISM MENGGUNAKAN ALGORITMA RABIN-KARP DAN JARO-WINKLER DISTANCE DENGAN,”pp. 1-6, 2017.

[3] HP FAUZAN AKBAR SINAGA, "Implementasi Algoritma Rabin Karp Pada Pendeteksian Pengulangan Kata Kerja Dalam Penulisan Bahasa Inggris," Univ. Sumatera Utara, 2017.

[4] S. Ramadhani, "Sistem Pencegahan Plagiarism Tugas Akhir Menggunakan Algoritma Rabin-Karp ( Studi Kasus: Sekolah Tinggi Teknik Payakumbuh )," vol. x, no. x, pp. 44-52, 2015.

[5] D. et al. 2013 Effendi, "Universitas Sumatera Utara 6," pp. 6-38, 2001.

[6] A. PRASTYANTI, "Sistem deteksi kemiripan kata pada dua dokumen menggunakan algoritma rabin-karp skripsi,” 2014. 